\title{
Procreation and Quality Analysis of Cow Curd by Using Starter Culture as Fermented Rice Rinsed Water
}

\section{Shilpa $\mathrm{J}^{1 *}$ and Sridevi $\mathrm{D}^{2}$}

${ }^{1}$ PSG Hospitals, Peelamedu, Coimbatore, India

${ }^{2}$ Nutrition and Dietetics, Dr. NGP Arts and Science College Coimbatore, India

\begin{abstract}
Lactic acid bacteria are a diverse group of bacteria that produce lactic acid as their major fermentation product. The LAB is widespread in nature and is beneficial probiotics in our digestive systems. Cow's milk offers a rich source of calcium for bone development. The protein in cow's milk is $20 \%$ whey protein and $80 \%$ casein protein.

The production of cow curd by fermentation of cow's milk with Lactobacillus planetarum which is isolated from rice rinsed water was studied. The efficacy of using rice rinsed water of $10 \%, 15 \%, 20 \%, 25 \%$ of prepared LAB solution is added to cow's milk (C1, C2, C3 and C4) as a starter culture. Fermentation of cow milk was done by using $20 \%$ of LAB solution which is noted as imparted beneficial effects of sensory, physiochemical, nutrient and microbial properties of curd. The overall acceptability was greatest for cow curd C3. crude protein content $(2.6 \mathrm{~g})$, fat $(5.0 \mathrm{~g})$, calcium of $100 \mathrm{mg}$ and lactose $(5.2 \mathrm{~g})$ were recorded from cow curd of $20 \%$. So this type of curd is recommended for weight watcher and ortho persons.
\end{abstract}

Keywords: Lactic acid bacteria; Cow's milk; Fermentation; Starter culture

\section{Introduction}

The LAB is used as natural or selected starters in food fermentations in which they perform acidification due to the production of lactic and acetic acids flavor. Protection of food from spoilage and pathogenic microorganisms by the $\mathrm{LAB}$ is through production of organic acids, hydrogen peroxide, and diacetyl, antifungal compounds such as fatty acids or phenylacetic acid and/or bacteriocins [1]. Probiotics are defined as "Living organisms which upon ingestion in certain number exert health benefits beyond inherent basic nutrition". LAB are useful for human being and animals in many aspects these include, prevention of diarrhoea, effects in lactose intolerance, treating ulcer, stimulation of immunity both at intestinal and systemic level, food preservation effects, antifungal activity, role in infectious diseases prevention, role in allergy, effects on the incidences of colon cancer and slow the progression of cancer, and produce many valuable dairy products [2]. Yogurt is considered as healthy food due to its high digestibility and bioavailability of nutrients and also can be recommended to the people with lactose intolerance, gastrointestinal disorders such as inflammatory bowel disease and irritable bowel disease, and aids in immune function and weight control. Because of these health benefits associated with yogurt consumption, there is an increasing trend for yogurt and is the fastest growing dairy category in the market, in particular, standard yogurt and yogurt drinks [3]. Global interest in rice and its fermented product is increasing due to their caloric value, unique quality, and high acceptability. Rice is a good source of carbohydrates (77-89 percentage) and energy (1460-1560 KJ). It also provides a moderate amount of protein (6.3-7.1 percentage), though it is devoid of lysine. There are many popular rice fermentation procedures used to make it more nutritious (i.e., enrichment with essential amino acids and removal of phytic acid, a major anti-nutrient in rice), easily digestible (as microbial enzymes predigest it), and acquire therapeutic properties (antimicrobial peptides, antioxidants, etc.) and symbiotic properties [4].

\section{Materials and Methods}

\section{Preparation of rice water}

Take $150 \mathrm{gm}$ of rice and $400 \mathrm{ml}$ of drinking water in a vessel. Soak the rice in this measured quantity of the water in a bowl. Kept it for half an hour. After half an hour filter the rice rinsed with water and rice water separately. Make sure that there is no rice in this collected rinsed water.

\section{Preparation of lab solution}

Fill a clean glass jar about two by third full with rice rinsed water. Cover the mouth of the jar with breathable cloth (such as muslin) or paper (not plastic) and secure with rubber bands or ties to keep out pests. Store at room temperature away from direct light. Be careful not to shake or move the jar while it ferments. After 5 days, LAB will multiply and give off a slightly sour odor. There will be a mat of semi-solid material floating on the top of the cloudy liquid in the jar. Collect only the cloudy liquid (fermented rinse-water) by pouring off and discarding the mat layer. Measure one part of fermented rinse-water and add 10 parts of milk to fill your jar $2 / 3$ full. As in the next step, cover the mouth of the jar with cloth or paper and secure with rubber bands or ties to keep out pests. Store at room temperature away from direct light. Be careful not to shake or move the jar while it ferments. After 2 to 3 days, the contents of the jar will separate into a floating solid fraction and a yellow liquid fraction. It may take longer in cooler climates. The yellow liquid is the LAB culture. Pour off the liquid fraction, being careful not to mix any solids back into the LAB culture. The preparation of LAB solution procedure was presented in Figure 1

\section{Preparation of fermented cow's milk}

Pure cow's milk is selected for the preparation curd. Cow's milk is boiled at the $100^{\circ} \mathrm{C}$. After that kept in room temperature till it reaches $40^{\circ} \mathrm{C}$. Add four different quantity of LAB solution (fermented rice rinsed water) as the starter culture in $\mathrm{C} 1, \mathrm{C} 2, \mathrm{C} 3$, and $\mathrm{C} 4$ variations of cow's

*Corresponding author: Shilpa J, Dietitian at PSG Hospitals, Peelamedu Coimbatore, India, Tel: 9788358788; E-mail: Shilpajoyanna1994@gmail.com

Received September 12, 2018; Accepted November 12, 2018; Published November 15, 2018

Citation: Shilpa J, Sridevi D (2018) Procreation and Quality Analysis of Cow Curd by Using Starter Culture as Fermented Rice Rinsed Water. J Food Process Technol 9: 767. doi: 10.4172/2157-7110.1000767

Copyright: (c) 2018 Shilpa J, et al. This is an open-access article distributed unde the terms of the Creative Commons Attribution License, which permits unrestricted use, distribution, and reproduction in any medium, provided the original author and source are credited. 
Wash rice grains (Rice $150 \mathrm{~g}$ and water $500 \mathrm{ml}$ )

Collect the first two rinses of cloudy water

Fill 2/3 of rice rinsed water in glass bottle

Cover the mouth of the jar with muslin cloth

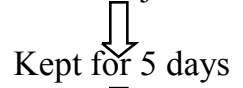

Collect cloudy liquid by filtering mat layer<smiles>[C-]1=CC=C1</smiles>

Add 1:10 parts of solution and milk

Cover the jar with cloth for 2 days

Separate into a floating sold mass and a yellow liquid

Yellow liquid is the LAB culture

Figure 1: Flow chart for preparation of lab solution.

milk respectively. Then kept it for overnight for normal fermentation of cow's milk to curd at room temperature.

\section{Organoleptic evaluation of fermented curds}

The evaluation of sensory attributes like color, flavor, taste, texture and overall acceptability was done using the scorecard. The cow curd variations which are formulated were evaluated using organoleptic evaluation by 25 semi-trained panel members. The most desired character to the particular quality carried the maximum score of 5 and least desired character minimum score of 1 . The five-point of hedonic rating scale was used for sensory evaluation.

\section{Physio-chemical analysis of selected curd from cow's milk}

The physiochemical characteristics such as moisture, Titrable acidity, $\mathrm{pH}$ were analyzed initially in the selected curd that formulated. All the work was done in the Food Science Laboratory of Dr. NGP Arts and Science College, Coimbatore. All the tests are done according to the AOAC method [5].

\section{Nutrient analysis of selected curd from cow's milk}

The nutrients like energy, protein, fat, fiber, calcium content were analyzed initially by using the standard procedure. All the work was done in Dr. NGP Arts and Science College. All the tests are done according to the AOAC method [6,7].

\section{Microbial analysis of selected curd from cow's milk}

The Total bacterial count, yeast mold count, bacteria type, lactic acid bacteria growth, MALDI TOFF test all these were analyzed in microbiology laboratory of Dr. NGP Arts and Science College, Coimbatore other than MALDI TOFF text.

\section{Statistical analysis of selected curd prepared from fermented rice rinsed water}

The data of each parameter were statistically analyzed. The result obtained was tabulated and statistically tools like mean and standard deviation were used to interpret the results.

\section{Results and Discussion}

\section{Mean sensory score of selected cow curd (c) prepared from lab solution}

Table 1 shows the result of sensory evaluation of cow curd variations prepared from different LAB premix containing $90 \%$ cow's milk and $10 \%$ lab solution $\mathrm{C} 1$ got least mean value for taste, texture, flavor, color and overall acceptability of $2.60,2.80,3.04,3.24$, and 2.36 respectively. It is evident that cow curd in the ratio of 80:20 (C3) which was obtained the best mean score of overall acceptability 4.04 by gave a very good point by the panel members (Figure 2).

Physio-chemical analysis of selected cow curd c3 (20\%) inoculated by lab solution

Table 2 presents the value of physiochemical parameters in the selected cow curd sample. The highly acceptable cow curd is prepared by using $20 \%$ of LAB solution (fermented rinsed water. The kind of probiotic culture and incubation temperature, time period significantly affects physicochemical characteristics of the sample. $\mathrm{pH}$, titrable acidity and moisture were measured in the selected curd. It was observed that the cow curd 4.6 of $\mathrm{pH}$ by the fermentation effect of lactic acid bacteria that converted the lactose in the milk into lactic acid.

Titrable acidity followed an increasing trend with the increased composition of cow's milk for curd preparation. Highest titrable acidity was seen in cow curd $1.35 \%$. Cow curd shows only low moisture content $84.0 \%$ level of moisture content. The lower level of moisture content

\begin{tabular}{|c|c|c|c|c|}
\hline Criteria & C1 (10\%) & C2 (15\%) & C3 (20\%) & C4 (25\%) \\
\hline Colour & $3.24 \pm 0.66$ & $3.72 \pm 0.79$ & $4.72 \pm 0.54$ & $4.16 \pm 0.62$ \\
\hline Flavour & $3.04 \pm 1.05$ & $3.80 \pm 1.04$ & $4.20 \pm 1.04$ & $3.12 \pm 1.12$ \\
\hline Texture & $2.80 \pm 1.15$ & $3.72 \pm 1.42$ & $4.76 \pm 0.52$ & $3.92 \pm 0.81$ \\
\hline Taste & $2.60 \pm 1.08$ & $3.36 \pm 1.38$ & $4.32 \pm 1.02$ & $2.88 \pm 1.28$ \\
\hline Overall acceptability & $2.36 \pm 0.99$ & $3.12 \pm 1.01$ & $4.04 \pm 0.67$ & $3.08 \pm 0.86$ \\
\hline
\end{tabular}

Table 1: Mean sensory score of cow curds (c) prepared from lab solution.

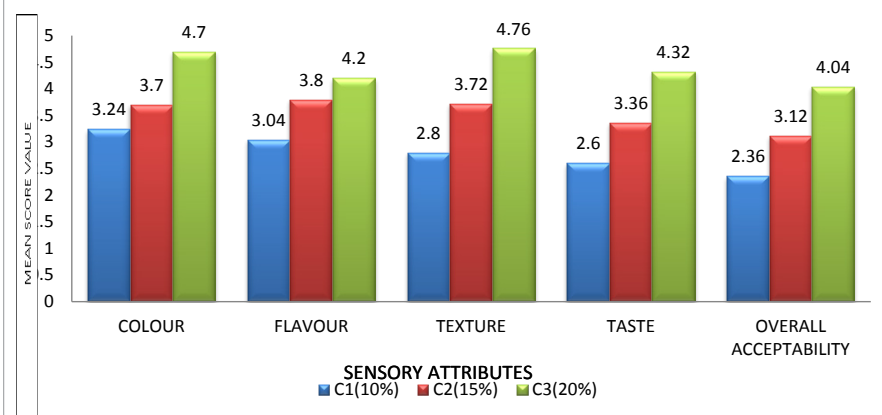

Figure 2: Overall acceptability of cow curds prepared from lab solution.

\begin{tabular}{|c|c|}
\hline Parameters & C3 (20\%) \\
\hline Ph & 4.6 \\
\hline Moisture (\%) & 84.0 \\
\hline Tritable acidy (\%) & 1.35 \\
\hline
\end{tabular}

Table 2: Physio-chemical analysis of selected cow curd inoculated by lab solution in $100 \mathrm{~g}$. 
in the curd says that there is high shelf life and not easily deteriorated because of the low microbial growth.

\section{Nutrient analysis of selected cow curd inoculated by lab solution}

Table 3 shows that the nutrient analysis of the selected curd which is inoculated with fermented rice rinsed water as the starter solution. While the protein was recorded for cow curd about $2.6 \mathrm{~g}$. It is interesting to note that the fat content that of cow curd $5.07 \mathrm{~g}$.

The total fiber content for cow curd C 3 was $0.2 \mathrm{~g}$ which can reduce blood fat, blood pressure, lower the level of cholesterol in the blood by that ion. It prevents coronary heart diseases and constipation. The mineral content calcium was in cow curd estimated about $100 \mathrm{mg}$. The lactose content that inoculated with fermented rice rinsed water was very much greater in cow curd C3 about $5.2 \mathrm{~g}$ so that it is a suitable economical substitute for cow curd and an ideal nutritional supplement for the lactose-intolerant population.

\section{Microbial analysis of the selected cow curd inoculated by lab solution}

Total plate count: In total plate count here we examined the total bacterial count, total yeast mold count in the selected cow curd which is inoculated with fermented rice rinsed water as the starter culture. The results are shown in Table 4.

Table 4 shows the counts of probiotic bacteria of the samples. And results demonstrated that the cow curd has a count of $13 \times 10^{-7} \mathrm{cfu} / \mathrm{g}$ and incubated at $37^{\circ} \mathrm{C}$ overnight. From the above table that yeast count and mold count found to be same for curd about $48 \times 10^{-5} \mathrm{cfu} / \mathrm{g}$.

Morphological identification of bacteria: The nine genera of bacteria were isolated from the sample. Three of bacteria are isolated from each selected curd of a cow. And it is kept it for $37^{\circ} \mathrm{C}$ for one day. The bacteria were isolated on nutrient agar and examined for colonial and morphological characterization.

Table 5 shows that results of morphological identification of nine genera that isolated from the selected curd samples. And it is kept it for $37^{\circ} \mathrm{C}$ for one day. The nine genera were lactobacillus. The morphological characterization indicates that all the isolates were round and large in size. It also showed that nine genera of isolates are rod-like bacteria, which means bacillus bacteria.

\begin{tabular}{|c|c|}
\hline Parameters & C3 (20\%) \\
\hline Protein $(\mathrm{gm})$ & 2.6 \\
\hline Fat $(\mathrm{gm})$ & 5.0 \\
\hline Fiber $(\mathrm{gm})$ & 0.2 \\
\hline Calcium $(\mathrm{mg})$ & 100 \\
\hline Lactose $(\mathrm{gm})$ & 5.2 \\
\hline
\end{tabular}

Table 3: Nutrient analysis of selected cow curds inoculated by lab solution in $100 \mathrm{~g}$

\begin{tabular}{|c|c|c|c|}
\hline Selected curd & Total bacterial count & Total yeast count & Total mould count \\
\hline C3 & $13 \times 10^{-7} \mathrm{cfu} / \mathrm{g}$ & $48 \times 10^{-5} \mathrm{cfu} / \mathrm{g}$ & $48 \times 10^{-5} \mathrm{cfu} / \mathrm{g}$ \\
\hline
\end{tabular}

Table 4: Total plate count.

\begin{tabular}{|c|c|c|c|c|c|}
\hline $\begin{array}{c}\text { Type of } \\
\text { curds }\end{array}$ & Isolates & Size & Shape & Colour & $\begin{array}{c}\text { Microcopy } \\
\text { identification }\end{array}$ \\
\hline \multirow{3}{*}{ Cow curd } & Cow $10^{-5}$ & Large & Round & Yellow & Bacilli \\
\cline { 2 - 6 } & Cow $10^{-6}$ & Large & Round & Creamy & Bacilli \\
\cline { 2 - 6 } & Cow $10^{-7}$ & Large & Round & Milky & Bacilli \\
\hline
\end{tabular}

Table 5: Morphological identification of bacteria.
Identification of bacterial type by using gram staining: The bacterial type of LAB isolated from naturally fermenting cow curd identified clearly by using gram staining method that was grampositive. It showed the bacteria isolated and their probable identity.

\section{Conclusion}

This study revealed that cow's milk C3 could be used for the preparation of high protein, less cholesterol and small curd saturated fatty acid. It can be recommended by this combination curd C 3 of cow's milk without any changes and it is a perfect alternative food than the usual cow curd. The amino acid cysteine in whey protein is a substrate for the synthesis of glutathione in the body which is a ubiquitous cellular antioxidant, laboratory experiments have suggested that whey protein and its components might reduce the risk of cancer in animals, suggesting an avenue for future medical research. Whey protein may, therefore, represent a novel approach for enhancing glucoselowering strategy in Types 2 Diabetes. Diet rich in protein and low in carbohydrate induce a decrease in calorie in obese subjects, resulting in greater weight loss than conventional energy-restricted, and lowfat diet. Increased dietary protein intake has been shown to increased overall weight loss and maintenance of lean body mass.

The formulated Fermented rice rinsed water ( $\mathrm{LAB}$ solution) is rich in $\mathrm{CHO}$, antioxidants, minerals, $\mathrm{B}$ vitamins, vitamin $\mathrm{E}$, and a trace amount of pitera. It helps to improve blood circulation, prevent agerelated spots, inflammation in the skin, hair protection and beautifying effect. The formulated fermented rice rinsed water which has 6 months of shelf life, so that this LAB solution can be used as a starter culture for curd preparation were curd is not easily available or for fermentation. This method of preparing LAB culture from rice grain to be used for the commercial purpose instead of using gelling agents for making commercial curds it will give more jelly-like curd without any food additives and side effect

\section{References}

1. De Vugst L, Vandamme E J (1994) Bacteriocins of lactic acid bacteria Microbiolal Genet Appl. London: Blackie Acad and professional.

2. Masood MI, Qadir MI, Shirazi JH, Khan IU (2011) Beneficial effects of lactic acid bacteria on human beings. Crit Rev Microbiol 37: 91-98.

3. McKinley MC (2005) The nutrition and health benefits of yoghurt. Int J Dairy Technol 58: 1-12.

4. Steinkraus.K.H (2002) Fermentations in world food processing. Compr Rev Food Sci Food Safety 1: 23-32.

5. AOAC (1995) Official methods of analysis. $16^{\text {th }}$ edition. association of officia agricultural chemists, Washington, DC.

6. Dugo P, Mondello L, Dugo L, Stancanelli R, Dugo G (2000) LC-MS for the identification of oxygen heterocyclic compounds in citrus essential oils. J Pharm Biomed Anal 24: 147-154

7. Hognadóttir A, Rouseff RL (2003) Identification of aroma active compounds in orange essence oil using gas chromatography-olfactometry and gas chromatography-mass spectrometry. J Chromatogr A 998: 201-211. 